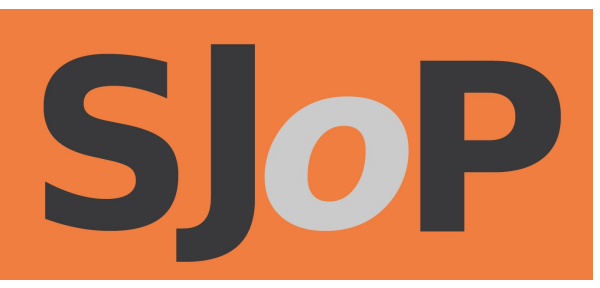

Book review: Rancière and film, edited by Paul Bowman

\title{
SAM BEATON
}

The Scottish Journal of Performance

Volume 2, Issue 1; December 2014

ISSN: 2054-1953 (Print) / ISSN: 2054-1961 (Online)

Publication details: http://www.scottishjournalofperformance.org

To cite this article: Beaton, S., 2014. Book review: Rancière and film, edited by Paul Bowman. Scottish Journal of Performance, 2(1): pp.129133.

To link to this article: http://dx.doi.org/10.14439/sjop.2014.0201.11

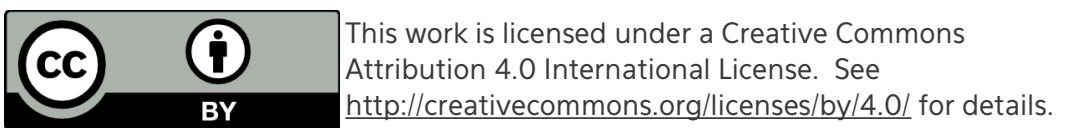




\title{
Book review: Rancière and film, edited by Paul Bowman
}

\author{
SAM BEATON
}

DOI: $10.14439 /$ sjop.2014.0201.11

Publication date: 15 December 2014

Rancière and film, edited by Paul Bowman. Edinburgh: Edinburgh University Press, 2013; ISBN: 9780748647354 (£24.99)

It is to the credit and overall success of Rancière and Film that the essays featured in the book both transcend film as merely features on cinema screens, and investigate Jacques Rancière's writing in wider-ranged terms than simply his later writing on the topic.

Paul Bowman, who incidentally maintains the useful ranciere.blogspot.co.uk website alongside Michael O'Rourke, is tasked with editing the volume. Although a preface introducing the chapters would have been desirable, he nonetheless sets out many of the key themes that run through Rancière's work, paying particular attention to his relationship to disciplines and disciplinarity. Bowman's overview on this point is helpful when considering subsequent chapters that investigate Rancière's place in film, media and cultural studies ${ }^{1}$. There is also a lot to be said for how the book is structured: despite the standalone nature of contributions, the order in which they appear is deliberate. For example, Nico Baumbach's essay, 'What Does It Mean to Call Film an Art?' is conveniently placed in the second chapter, offering clear and concise models of categorising film as art which, in a book that deals heavily in aesthetics, is a helpful point of reference for subsequent passages. 
In several cases, authors discuss a point that is developed further in succeeding chapters. For example, Richard Stamp's well-researched investigation into animator John Whitney cites 'Stanley Cavell's point when he criticizes (academic) film for "getting technical", the only relevant technical issues being those in front of the spectator's eyes' $(\mathrm{p} .165)^{2}$. Not only is this a neat, if slightly condensed understanding of Rancière's own prioritisation of spectatorship over medium-specificity in viewing film, it also provides a segue into James A. Steintrager's chapter where he employs The Future of the Image (2007) amongst other texts to elaborate on the Rancièrean rejection of 'the materialist determinism of dominant discourses about images and mediation' (p.169). By using sources written at a time where some claimed digital media (such as the internet) would bring around the end of film's dominance, Steintrager shows with great clarity why Rancière opposes film study that fetishises the medium over the image itself. The thought-provoking questions he posits on this point are succinct, identifying the flaws in this mediological discourse:

What happens when a film is shown on television? Even given the different apparatuses of diffusion, is a television camera significantly different from a movie camera? What happens when both television and cinema images are captured, processed or created digitally? (p.172)

Steintrager's summary of these problems goes to the heart of what is still a much-debated issue in the field of film studies. Rather than being in the author's words 'simplistic' (ibid.), however, what is contained in the chapter is a readable and reasoned argument that holds a great deal of value in this area, arguably more so than some of the more theory-heavy pieces that are occasionally rather difficult to follow. 
The range and scope of the essays within Rancière and Film are too numerous to do justice in this review, including Rancière's own postface setting out his agreements and, where necessary, clarifications. Nevertheless, there are two further chapters deserving of attention here. As mentioned earlier, there is more to this book than just feature film: although features have been employed as examples throughout some pieces, animation and documentary (including 'false documentary' or docufiction) are also focused on. A decade on from Dina Iordanova's observation that documentary film is 'the least explored cinematic form' (2003, p.19), this development is to be welcomed. Rey Chow's 'After the Package of the Beast' sets out to explain the relationship of sound to the representation and authenticity of the documentary and-as alluded to previously-the 'false documentary' (in this case Resnais's Hiroshima mon amour (1959)) that copies elements of technique or style while being based in fiction. Valuable points are raised throughout, with the distinction of 'documentary's claim to be, and assumed status as, a truthful record, transcript or repository' (p.35, emphasis mine) perhaps being the most crucial in understanding non-fiction film as being an explanation of reality as opposed to pure objectivity. This avenue is subsequently developed by Bram Ieven's study of medium-specificity, modernism and the historical validity of the documentary. Particularly interesting is Rancière's idea of the fable, which is not solely within the realm of feature film: that 'documentary must draw on the same sources and methods as the feature film' (p.94) is an often-missed observation that demonstrates non-fiction's need for image and signs, as much as any other genre. Using director Chris Marker in his arguments, the essay is of great use to those who take an interest in the documentary form.

Although some elements could perhaps be clearer, and prefaced more successfully, the sheer amount of research, scope of contributions and argument put into Rancière and 
Film make it an engaging and thought-provoking text for study into Rancière's writings and of film study. Researchers in the field will find much to praise as the scholars critically engage with the material and frame new angles for consideration, leading to a far more enriching experience than merely spelling out where they believe the answers lie. Informative and provoking, it is a welcome encouragement to explore film study further.

\section{Notes}

1. Rancière himself alludes to this question in the postface: 'I have never in my life given a single lecture on film theory nor have I taught in a "film studies" department. Neither have I ever been a cinema critic' (p.185).

2. The first chapter in Cavell's The World Viewed takes up the question of 'what is art?' and the relation to cinema (pp.3-16), again underpinning the usefulness of Baumbach's categorisations.

\section{References}

Bowman, P. and O'Rourke, M., 2014 Jacques Rancière: focusing on the work of Jacques Rancière. [online]. Available at:

〈http://ranciere.blogspot.co.uk $\rangle$ [Accessed 26 ${ }^{\text {th }}$ August 2014].

Cavell, S., 1979. The world viewed. Enlarged edition. Cambridge, MA: Harvard University Press.

Iordanova, D., 2003. Cinema of the other Europe: the industry and artistry of East Central European film. London: Wallflower Press.

Rancière, J., 2007. The future of the image. Translated from French by Gregory Elliott. New York and London: Verso. 


\section{About the review author}

SAM BEATON is a PhD candidate in Czech Studies at the University of Glasgow, funded by the Madeleine Albright Scholarship. His research investigates the longitudinal documentaries of Helena Třeštíková, paying close attention to changes in style and language brought on by the Czechoslovak transition from state socialism to liberal democracy. He has a wider interest in Central and East European feature film, and contributes reviews and opinion pieces to Czech online journal Britské listy. 